- scientists into a research council concerned primarily with distributing grants.

CNRS now gives research funds to its laboratories to spend as they see fit. But one proposal in the circular is that CNRS spend almost half its funds on a series of new research 'programmes', with funding awarded to individual research groups on the basis of peer review of grant proposals.

The circular claims that the goal of this is to improve the effectiveness and "dynamism" of research. But the trade unions argue that the main objective of the reforms is to shift control of research from the research organizations to the science ministry, and to reorient research towards political and economic goals.

Bernard Bigot, head of the science and technology commission at the research ministry, has said that one goal of the reforms is to strengthen the link between CNRS research and national objectives. Such objectives will be fixed by a 'Strategic Committee of Orientation' to be created within the science ministry next month.

CNRS has 27,000 staff, and a welldeveloped structure for implementing its research strategy. But, claim the unions, its political independence has become an obstacle to Fillon's plans to orient research towards national priorities. They describe the reforms as a "dilution of the CNRS's role, and an explosion of its structures".

The circular suggests that "administrative and scientific" control of more than half of CNRS laboratories - mainly those already 'associated' with universities - would pass to the universities, although theses would be free to apply for grants from the proposed CNRS programmes.

CNRS has yet to make any public comment on the proposed changes. But many scientists are concerned that universities, already hard-pressed to recruit the staff needed to keep pace with burgeoning student numbers, might not be able to afford to maintain new laboratories adequately.

The main concern, says Henri-Edouard Audier, a chemist at the Ecole Polytechnique, is that the government is being driven not primarily by considerations of research but by a desire to cut costs. By reducing the number of CNRS laboratories, it hopes to release funds for the planned strategic research programmes, he claims.

Furthermore, although France has many first-class research universities, not only in Paris but also, for example, in Lyons, Marseilles and Strasbourg, many are oriented primarily towards teaching, and lack the research traditions of their Anglo-Saxon counterparts. Some are also rife with nepotism, political wrangling and mediocrity.

Audier also claims that a proposal to reduce the number of CNRS scientific departments from seven to three - social sciences, life sciences and material sciences and engineering - is only a first step towards slimming CNRS down further.

Declan Butler

\title{
Hewlett and Packard boost support for basic research
}

San Francisco \& Cambridge, UK. The US computer and instrument company HewlettPackard last week became the source of two separate grants aimed at supporting basic research, acknowledging its founders' belief in the past (and future) contribution of such research to their company's fortunes.

In California, William R. Hewlett and David Packard, two of the original Silicon Valley pioneers, announced a joint gift of $\$ 77.4$ million to Stanford University, where they first met in the 1930s. The gift - the single largest in Stanford's history - completes the financing needed for a $\$ 175$ million, ninebuilding science and engineering complex.

In a separate development, the president of Britain's Royal Society, Sir Michael Atiyah, formally inaugurated a new Basic Research Institute in the Mathematical Sciences

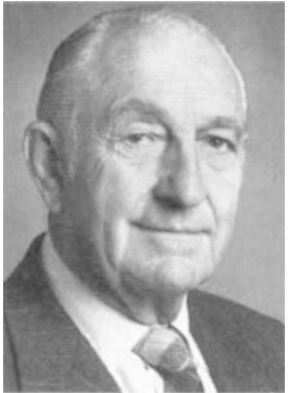

Packard: eyes on long-term strategy.
(BRIMS), based at Hewlett-Packard's research laboratories in Bristol.

BRIMS will have close links with the Isaac Newton Institute in Cambridge, of which Sir Michael is the director. The company will also finance a fellowship at the Newton Institute, funding its first full-time staff member.

The gift to Stanford will pay for the construction of four major buildings, as well as the demolition of several existing ones to make room for them. The project began in the early 1980 s with a pledge of $\$ 40$ million by Hewlett and Packard. The complete design is centred on a wooded courtyard and is intended to foster collaboration between disciplines, according to David Glen, principal gift director at Stanford.

"We've tried to look at the way our scientists do science and to design a campus that meets their needs - not only for science, but also for teaching," says Glen. He adds that the proximity of the scientific laboratories to humanities and business would help to realize Hewlett and Packard's vision of graduates who have a broad understanding of a variety of disciplines.

An electrical engineering building, together with the new Gates Information Science Building - made possible by a \$6million donation from Bill Gates of Microsoft Corporation - and the expansion of the Center for Integrated Systems, will combine research and studies in both computer hardware and software.
A laboratory for advanced materials research will allow chemists to work closely with engineers, while a statistics department building will be placed next to a new complex of lecture halls and classrooms. The entire new section will be close to the university's medical centre and biology buildings.

In a joint statement, Hewlett and Packard, who were both members of Stanford's class of 1934, said: "We believe this gift will ensure that Stanford University will have leadership in science and engineering second to none during the suede century."

The new UK institute is intended to give the company's researchers in Europe and the United States access to advanced mathematical thinking - particularly in areas such as nonlinear mathematics - which is likely to provide the underpinning of future developments in fields ranging from quantum devices to broadband networking.

According to John Taylor, the director of the HP Laboratories in Bristol at which BRIMS will be based, the institute is being financed from money that the company has set aside at the personal direction of David Packard to support basic research. Packard stepped down as chairman in September but remains chairman emeritus.

"Last year, Packard said that it would be okay to spend some resources on long-range topics, and that has given us permission to resist pressure from the rest of the company and work on things that have no particular application at the present," says Taylor.

At the same time, Taylor points out that non-linear mathematics has potential relevance to many parts of the company's business, such as soliton propagation in optical fibres, the chaotic modelling of cardiac arrhythmia and the statistical mechanics of very large networks.

The Newton Institute, which was opened two years ago, will provide support for short courses on advanced mathematics at Bristol and will also reinforce the activities of BRIMS in other ways. In return, the company has provided the institute with 10 new computers, as well as financing the research fellow in Cambridge and another shared appointment with the University of Bristol.

Atiyah says that Hewlett-Packard's backing for the Cambridge institute will have no direct influence on its choice of research topics. At the same time, he is keen to emphasize that, with university researchers being urged to contribute towards wealth creation, the new deal illustrates how even basic mathematics can play its part. "It is in the spirit of last year's white paper on science and technology," he says.

Sally Lehrman \& David Dickson 